\title{
ANALISIS PENGARUH PEMBERIAN MODAL KERJA DAN BIAYA PRODUKSI TERHADAP PENINGKATAN PENDAPATAN USAHA KECIL MENENGAH DI DESA PONGKAR KECAMATAN TEBING KABUPATEN KARIMUN (TAHUN 2014 - 2018)
}

\author{
${ }^{1}$ Fauzan Haqiqi , ${ }^{2}$ Rahma Dewi Susanti , ${ }^{3}$ Ferawati \\ ${ }^{1}$ Program Studi Akuntansi, Fakultas Ilmu Sosial dan Humaniora, Universitas Karimun, \\ Provinsi Kepulauan Riau, Indonesia \\ Email : fauzanhaqiqi.1986@gmail.com \\ ${ }^{2}$ Program Studi Akuntansi, Fakultas Ilmu Sosial dan Humaniora, Universitas Karimun, \\ Provinsi Kepulauan Riau, Indonesia. \\ Email : rahmadewisusanti86@gmail.com \\ ${ }^{3}$ Program Studi Akuntansi, Fakultas Ilmu Sosial dan Humaniora, Universitas Karimun, \\ Provinsi Kepulauan Riau, Indonesia. \\ Email : fera.universitaskarimun@gmail.com
}

\begin{abstract}
Abstrak
Rahma Dewi Susanti 2019, Analisis Pengaruh Pemberian Modal Kerja dan Biaya Produksi terhadap Peningkatan Pendapatan Usaha Kecil Menengah di Desa Pongkar Kecematan Tebing Kabupaten Karimun Tahun 2014-2018.

Pada penelitian ini variabel yang diteliti adalah Pemberian Modal Kerja dan Biaya Produksi yang mana keduanya merupakan variabel independent. Sedangkan Pendapatan merupakan variable dependent. Data yang digunakan dalam penelitian ini adalah data panel karena gabungan antara cross section data 7 Usaha Kecil Menengah di Desa Pongkar Kecematan Tebing Kabupaten Karimun yang sifatnya time series yaitu Kerpuk Udang Super, Bangkit Hazanah, Bolu Bakar, Kue Lepis Legit, Kencana Snack Kerupuk Tenggiri, Industri Keripik Pisang, dan Kerupuk Udang Mentah pada tahun 2014 - 2018. Jenis penelitian ini adalah penelitian kuantitatif analisis deskriptif dengan metode analisis data yang digunakan adalah model Regresi Data Panel.

Hasil penelitian ini menunjukkan Pemberian Modal Kerja dan Biaya Produksi berpengaruh signifikan terhadap Peningkatan Pendapatan Usaha Kecil Menengah di Desa Pongkar Kecematan Tebing Kabupaten Karimun
\end{abstract}

Kata Kunci : Pemberian Modal Keja, Biaya Produksi dan Pendapatan.

\section{PENDAHULUAN}

Peningkatan pendapatan dalam suatu kegiatan usaha yang telah dilakukan dalam periode tertentu sangat penting bagi setiap pengusaha, antara lain untuk meningkatkan 
pendapatan. dengan meningkatnya pendapatan maka perusahaan atau UMKM dapat dikatakan mengalami perkembangan yang positif.

Di dalam suatu perusahan ataupun UMKM ternyata tidak sepenuhnya mengalami perkembangan positif, perkembangan usaha juga bisa membawa ke dampat yang negatif atau masalah yang sering dihadapi dalam dunia usaha umumnya adalah kurangnya permodalan, kemitraan, serta peluang usaha. Permasalahan tersebut dapat menghambat tumbuh dan berkembangnya suatu usaha. Untuk mencapai suatu keberhasilan dalam usaha diperlukan dana yang cukup. Salah satu alternatif untuk mencapai keberhasilan diperlukan manajemen keuangan yang baik yang berawal dari penataan modal awal alternatif untuk mencapai keberhasilan diperlukan manajemen keuangan yang baik yang berawal dari penataan modal awal.

Berdasarkan latar belakang tersebut maka penulis dapat mengidentifikasi permasalahan sebagai berikut :

1. Belum semua pelaku UMKM menyadari bahwa peningkatan pendapatan usaha itu dipengaruhi oleh besar kecilnya modal kerja dan biaya produksi yang di kelola dengan bijak.

2. Belum adanya perhatian dan penanganan secara mendalam mengenai modal kerja dan biaya produksi yang berpengaruh terhadap kemajuan usaha.

3. UMKM masih menghadapi kendala dalam hal akses modal dan pendanaan.

\section{A. Teori Agency}

Teori keagenan mendeskripsikan hubungan antara pemegang saham (share holders) sebagai prinsipal dan manajemen sebagai agen. Manajemen merupakan pihak yang di kontrak oleh pemegang saham untuk bekerja demi kepentingan pemegang saham. Karena mereka dipilih, maka pihak manajemen harus mempertanggungjawabkan semua pekerjaannya kepada pemegang saham. Jensen dan Meckling (1976) menjelaskan hubungan keagenan sebagai "agency relationship as a contract under which one or more person (the agent) to perform some service on their behalf which involves delegating some decision making authority to the agent".

\section{B. Modal Kerja}

Untuk menjalankan usaha seorang pedagang membutuhkan modal yang nilainya bervariasi (Sudaryono,2017:333). Modal merupakan salah satu faktor yang penting yang berpengaruh terhadap pendapatan usaha. Peran modal dalam suatu usaha sangat penting karena sebagai alat produksi suatu barang dan jasa. Suatu usaha tanpa adanya modal sebagai salah satu faktor produksinya tidak akan dapat berjalan. Menurut Wicaksono dalam Vijayanti dan Yasa (2016:158), menyatakan bahwa faktor modal seringkali memberikan pengaruh terhadap suatu usaha dagang, dimana dapat berdampak pada timbulnya permasalahan lain seperti modal yang dimiliki seadanya, maka seseorang hanya mampu membuka usaha dagangnya tanpa bisa memaksimalkan usahanya. 


\section{Biaya Produksi}

Menurut Supriyono (2013:16), biaya adalah harga perolehan yang dikorbankan atau digandakan dalam rangka memperoleh penghasilan (revenues) dan akan dipakai sebagai pengurang penghasilan. Biaya digolongkan ke dalam harga pokok penjualan, biaya penjualan, biaya administrasi dan umum, biaya bunga dan biaya pajak perseroan. Sejalan dengan pendapatan di atas, Sampurno Wibowo dan Yani Meilani (2009:1-9), menyebutkan biaya atau cost adalah harga perolehan yang digunakan untuk memperoleh pendapatan (revenue) sehingga akan mengurangi penghasilan.

Sedangkan produksi menurut Supriyono (2013:57), adalah kegiatan pengolah bahan baku menjadi produk selesai. Pada kegiatan tersebut akan dikonsumsi bahan baku, tenaga kerja langsung, barang dan jasa lainnya yang dikelompokkan dalam overhead pabrik. Supriyono (2013:18), mengemukakan fungsi produksi adalah fungsi yang berhubungan dengan kegiatan pengolahan bahan baku menjadi produk selesai yang siap untuk dijual. Produksi melibatkan semua kegiatan yang berkaitan dengan penyediaan barang dan jasa. Jadi, pemakaian pekerja (dari tenaga kerja yang tidak berketerampilan sampai manajemen puncak). Pelatihan personalia, dan struktur organisasi yang dipergunakan untuk memaksimumkan produktifitas semuanya merupakan bagian dari proses produksi. Perolehan sumber daya modal dan penggunaan sumber daya yang efisien juga merupakan bagian dari produksi. Pada dasarnya usaha kecil menengah bertujuan untuk mendapatkan laba dengan memperoleh pendapatan dan membandingkannya dengan tenaga kerja yang dilakukan

\section{Peningkatan Pendapatan UMKM}

Meningkatnya pendapatan merupakan unsur yang sangat penting dalam sebuah usaha perdagangan, karena dalam melakukan suatu usaha tentu ingin mengetahui nilai atau jumlah pendapatan yang diperoleh selama melakukan usaha tersebut (Sihaloho, 2013:4). Terdapat beberapa pengertian tentang pendapatan. Tohar menyatakan bahwa secara umum ada dua segi pengertian dari pendapatan, yaitu dalam arti riil dan dalam arti jumlah luar. Pendapatan dalam arti riil adalah nilai jumlah produksi barang dan jasa yang dihasilkan oleh masyarakat selama jangka waktu tertentu.

Sedangkan pendapatan dalam arti jumlah uang merupakan penerimaan yang diterimanya, bisa dalam bentuk upah dari bekerja atau uang hasil penjualan, dan lain sebagainya (Nurul Huda, 2009:21). Pendapatan menurut ilmu ekonomi merupakan nilai maksimum yang dikonsumsi oleh seseorang dalam suatu periode dengan mengharapkan keadaan yang sama pada akhir priode seperti keadaan semula. Tingkat pendapatan per kapita dapat mencerminkan daya beli. Makin tinggi tingkat pendapatan, daya beli makin kuat, sehingga permintaan terhadap suatu barang meningkat (Pratama, 2010:25).

\section{METODE PENELITIAN}




\section{A. Jenis dan Sumber Data}

Penelitian dilaksanakan di daerah Tanjung balai karimun, dengan objek penelitian pada pelaku Usaha Mikro Kecil Menengah yang dikelola langsung pemerintahan desa di Desa Pongkar Kecamatan Tebing Kabupaten Karimun Provinsi Kepulauan Riau. Lokasi penelitian ini dipilih karena memiliki semua aspek pendukung agar penelitian berjalan dengan baik. Dalam penelitian ini terdapat 3 variabel penelitian yaitu variabel $X_{1}$, variabel $X_{2}$, dan variabel $Y$. Dimana variabel $X_{1}$ adalah modal kerja, Variabel $\mathrm{X}_{2}$ adalah biaya produksi, dan variabel $\mathrm{Y}$ adalah Pendapatan Usaha Mikro Kecil Menengah. Desa Pongkar Kecamatan Tebing Kabupaten Karimun sebagai variabel terikat.

Tabel Variabel Penelitian Dan Defenisi Operasional

\begin{tabular}{|c|c|}
\hline Variabel Penelitian & Indikator \\
\hline $\begin{array}{l}\text { Pemberian Modal Kerja (Variabel } \\
\mathbf{X}_{1} \text { ) "investasi perusahaan dalam } \\
\text { bentuk uang tunai, surat berharga, } \\
\text { piutang, dan persediaan dikurangi }\end{array}$ & $\begin{array}{l}\text { 1. Aktiva Lancar } \\
\text { 2. Hutang Lancar }\end{array}$ \\
\hline $\begin{array}{l}\text { kewajiban lancar yang digunakan } \\
\text { untuk pembiayaan aktiva lancar. }\end{array}$ & $\mathrm{AL}-\mathrm{HL}$ \\
\hline $\begin{array}{l}\text { Biaya Produksi (Variabel } \mathbf{X}_{2} \text { ) } \\
\text { "biaya-biaya yang digunakan dalam } \\
\text { proses produksi meliputi biaya bahan } \\
\text { baku, biaya tenaga kerja langsung dan } \\
\text { biaya overhead pabrik yang jumlahnya }\end{array}$ & $\begin{array}{l}\text { 1. Biaya Bahan Baku } \\
\text { 2. Biaya Tenaga Kerja } \\
\text { 3. Biaya Overhead Pabrik }\end{array}$ \\
\hline $\begin{array}{l}\text { lebih besar dibandingkan dengan jenis } \\
\text { biaya lain. }\end{array}$ & $\mathrm{BBB}+\mathrm{BTK}+\mathrm{BOP}$ \\
\hline $\begin{array}{l}\text { Peningkatan Pendapatan UMKM } \\
\text { (Variabel Y) "keadaan dimana suatu } \\
\text { usaha semakin maju dan berkembang. } \\
\text { Kemajuan usaha dapat dilihat dari } \\
\text { semakin banyak laba yang dihasikan } \\
\text { dari usaha tersebut }\end{array}$ & 1. Pendapatan operasional \\
\hline
\end{tabular}

\section{B. Populasi dan Sampel}

Keseluruhan pelaku UMKM di Desa Pongkar, Kecamatan Tebing, Kabupaten Karimun yang berjumlah 35 UMKM. Sugiono (2016:215) Memberikan pengertian bahwa sampel adalah sebagian dari jumlah dan karateristik yang dimiliki oleh populasi. Metode penelitian secara sampling yang merupakan suatu cara pengumpulan data yang sifatnya tidak menyeluruh, artinya tidak mencakup seluruh subjek penelitian, akan tetapi hanya sebagian dari populasi saja. 
Adapun kriteria perusahaan yang dijadikan sampel dalam penelitian ini adalah sebagai berikut:

a. Masih beroperasi sejak 2013 sampai dengan 2018.

b. Di biayai oleh BUMDES

c. Rekomendasi dari Dinas Koperasi dan UMKM Tanjung Balai Karimun.

d. Memiliki laporan keuangan yang layak untuk dianalisa.

\section{Metode Analisis Data}

1) Uji Normalitas

Dalam penelitian ini menggunakan uji normalitas dengan Jarque-Bera (JB Test). Uji ini dilakukan dengan membandingkan statistik Jarque-Bera (JB) dengan nilai $\mathrm{X}_{2}$ tabel. Jika nilai Jarque-Bera $(\mathrm{JB}) \leq \mathrm{X}_{2}$ tabel maka nilai residual terstandarisasi dinyatakan berdistribusi normal. Untuk menghitung nilai statistika Jarque-Bera (JB) digunakan rumus sebagai berikut: (Suliyanto, ${ }^{2011}$ :69).

$$
\mathrm{JB}=\mathrm{n}\left[\frac{\mathrm{S}^{2}}{6}+\frac{(\mathrm{K}-3)^{2}}{24}\right]
$$

2) Uji Multikolineritas

Multikolinearitas berarti adanya hubungan linear yang sempurna di antara variabel-variabel bebas dalam model regresi. (J. Supranto, 2010:13) Multikolinearitas dalam arti yang lebih luas, yaitu untuk terjadinya korelasi linear yang tinggi di antara variabel-variabel bebas $\left(\mathrm{X}_{1}, \mathrm{X}_{2}, \ldots, \mathrm{X}_{\mathrm{p}}\right)$. (Setiawan' ${ }^{2010}$ :84) Uji multikolinearitas bertujuan untuk menguji apakah dalam model regresi yang terbentuk ada korelasi yang tinggi atau sempurna di antara variabel bebas atau tidak. Jika dalam model regresi yang terbentuk terdapat korelasi yang tinggi atau sempurna di antara variabel bebas maka model regresi tersebut dinyatakan mengandung gejala multikolinier (Suliyanto, ${ }^{2011}: 82$ ).

3) Uji Autokorelasi

Uji autokorelasi bertujuan untuk mengetahui apakah ada korelasi antara anggota serangkaian data observasi yang diuraikan menurut waktu (time-series) atau ruang (cross-section). Dalam penelitian ini, peneliti menggunakan metode Uji Durbin Watson (Durbin Watson Test). Uji D-W merupakan uji yang sangat populer untuk menguji ada-tidaknya masalah autokorelasi dari model empiris yang diestimasi. Rumus yang digunakan untuk uji Durbin-Watson adalah:

$D W=\frac{\sum\left(\mathrm{e}-\mathrm{e}_{\mathrm{t}-1}\right)^{2}}{\sum \mathrm{e}_{\mathrm{t}}^{2}}$

\section{Uji Model Regresi Data Panel}

1) Uji Chow

Uji Chow yakni pengujian untuk menentukan model Fixed Effect atau Random Effect yang paling tepat digunakan dalam mengestimasi data panel. Rumus yang digunakan dalam uji chow ini adalah (Bambang Juanda, ${ }^{2012}: 83$ ): 


$$
\text { CHOW }=\frac{\mathrm{N}-1}{\mathrm{NT}-\mathrm{N}-\mathrm{K}}
$$

\section{2) Uji Hausman test}

Hausman test adalah pengujian statistik untuk memilih apakah model Fixed Effect atau Random Effect yang paling tepat digunakan. Pengujian uji hausman dilakukan dengan hipotesis berikut:

$\mathrm{H}_{0}=$ Model menggunakan pendekatan random effect

$\mathrm{H}_{1}=$ Model menggunakan pendekatan fixed effect

\section{E. Uji Hipotesis Regresi Data Panel}

1) Uji t

Uji t merupakan suatu pengujian yang bertujuan untuk mengetahui apakah koefisien regresi signifikan atau tidak. Sebelum melakukan pengujian, biasanya dibuat hipotesis terlebih dahulu (Nahrowi , 2002:24).

2) Uji F

Uji $F$ digunakan untuk mengevaluasi pengaruh semua variabel independen terhadap variabel dependen atau merupakan uji signifikansi model regresi (Agus Wisarjono, $\left.{ }^{2015}: 19\right)$.

3) Koefesien Determinasi $\left(\mathrm{R}^{2}\right)$

Koefisien determinasi $\mathrm{R}^{2}$ digunakan untuk mengukur seberapa baik garis regresi sesuai dengan data aktualnya (goodness of fit). Koefisien determinasi ini mengukur presentase total variasi variabel dependen $\mathrm{Y}$ yang dijelaskan oleh variabel independen di dalam garis regresi (Agus Wisarjono, ${ }^{2015}: 17$ ).

\section{HASIL DAN PEMBAHASAN}

\section{A. Uji t}

Uji statistik t dilakukan untuk melihat besarnya pengaruh dari tiap-tiap variabel bebas terhadap variabel terikat. Dari hasil regresi data panel dapat hasil sebagai berikut :

1) Hipotesis 1

Hipotesis pertama dalam penelitian ini adalah terdapat pengaruh signifikan positif (+) pemberian modal kerja $\left(\mathrm{X}_{1}\right)$ terhadap pendapatan Usaha Kecil Menengah di Desa Pongkar Kecamatan Tebing Kabupaten Karimun (Y). Berdasarkan olahan data pada Tabel 4.9 dapat dilihat nilai $t_{\text {hitung }}$ dari pemberian modal kerja diperoleh nilai $\mathrm{t}_{\text {hitung }} \geq \mathrm{t}$ tabel $(3.036668 \geq 0,2826)$ maka Ho ditolak dan Ha diterima. Dari data yang diperoleh bahwa pengaruh signifikan positif $(+)$ antara variable pemberian modal kerja $\left(\mathrm{X}_{1}\right)$ terhadap pendapatan Usaha Kecil Menengah di Desa Pongkar Kecamatan Tebing Kabupaten Karimun (Y). 


\section{2) Hipotesis 2}

Hipotesis kedua dalam penelitian ini adalah terdapat pengaruh signifikan biaya produksi $\left(\mathrm{X}_{2}\right)$ terhadap pendapatan Usaha Kecil Menengah di Desa Pongkar Kecamatan Tebing Kabupaten Karimun (Y). Berdasarkan olahan data pada Tabel 4.9 dapat dilihat

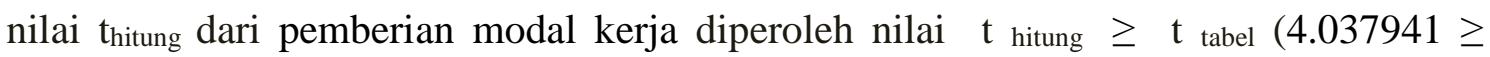
0,2826) maka Ho ditolak dan Ha diterima. Dari data yang diperoleh bahwa pengaruh signifikan antara variable biaya produksi $\left(\mathrm{X}_{2}\right)$ terhadap pendapatan Usaha Kecil Menengah di Desa Pongkar Kecamatan Tebing Kabupaten Karimun (Y).

\section{B. Uji F}

Dependent Variable: Y

Method: Panel EGLS (Cross-section random effects)

Date: 10/27/19 Time: 15:44

Sample: 20142018

Periods included: 5

Cross-sections included: 7

Total panel (balanced) observations: 35

Swamy and Arora estimator of component variances

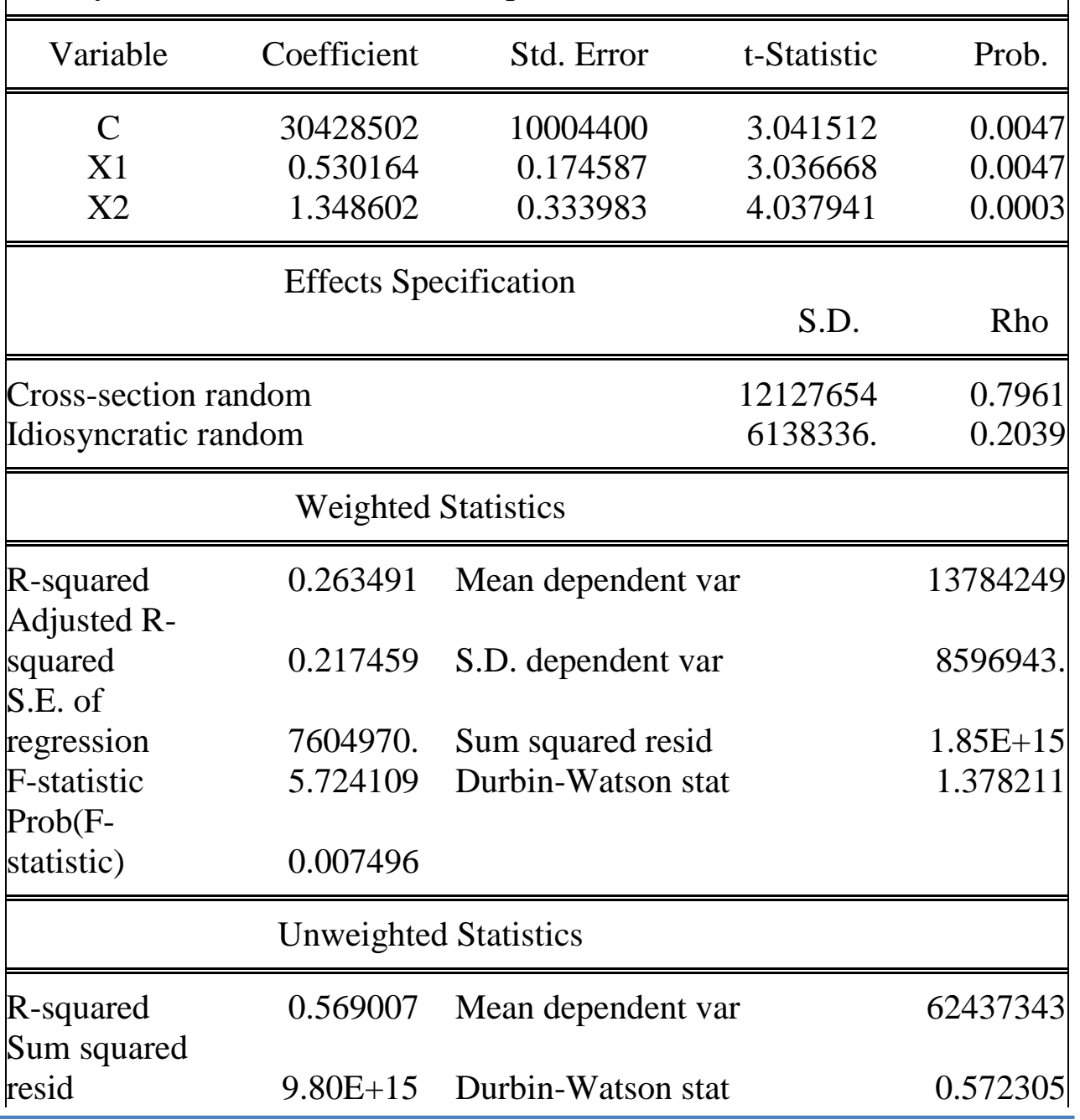




\section{Sumber: Data diolah, Tahun 2019.}

Hipotesis tahap kedua penelitian ini adalah terdapat pengaruh yang signifikan antara pemberian modal kerja, dan biaya produksi terhadap pendapatan Usaha Kecil Menengah di Desa Pongkar Kecamatan Tebing Kabupaten Karimun. Pengkajian hipotesis secara simultan dilakukan dengan menggunakan uji F. Jika $F_{\text {hitung }} \geq F_{\text {tabel }}$, maka Ho ditolak dan Ha diterima, artinya bahwa secara simultan variabel bebas berpengaruh terhadap variabel terikat.

Berdasarkan analisis data pada di atas dapat dilihat nilai $F_{\text {hitung }}$ dalam penelitian ini sebesar 0.007496 atau signifikan yang diperoleh adalah 0,000 pada $\alpha=0,05$, berarti nilai $F_{\text {hitung }}=0.007496<$ alpha 0,05. Dengan demikian Ho ditolak dan Ha diterima sehingga hipotesis yang diajukan dalam penelitian ini diterima, bahwa terdapat pengaruh signifikan antara pemberian modal kerja dan biaya produksi terhadap pendapatan Usaha Kecil Menengah di Desa Pongkar Kecamatan Tebing Kabupaten Karimun.

\section{Uji Deteminasi}

Koefisien determinasi $\left(\mathrm{R}^{2}\right)$ digunakan untuk melihat atau mengetahui konstribusi variabel bebas dalam menjelaskan variabel terikat. Nilai $\mathrm{R}^{2}$ berkisar antara nol dan satu $\left(0<\mathrm{R}^{2}<1\right)$. Nilai $\mathrm{R}^{2}$ yang kecil atau mendekati nol berarti kemampuan variabel independen dalam menjelaskan variasi-variabel dependen amat terbatas. Sebaliknya, jika nilai $\mathrm{R}^{2}$ mendekati satu berarti variabel independen memberikan hampir semua informasi yang dibutuhkan untuk memprediksi variasi variabel dependen, dan model tersebut dapat dikatakan baik.

Berdasarkan hasil estimasi seperti disajikan tabel dibawah ini diperoleh nilai RSquare $\left(\mathrm{R}^{2}\right)$ sebesar 0.263491 , artinya sebesar 26,3 persen variable persen variable pemberian modal kerja $\mathrm{X}^{1}$ dan biaya produksi $\mathrm{X}^{2}$ berpengaruh terhadap variable pendapatan Usaha Kecil Menengah di Desa Pongkar Kecamatan Tebing Kabupaten Karimun (Y), selebihnya dipengaruhi oleh variable lain yang tidak dijelaskan dalam penelitian ini (74,7 Persen)

Untuk membuktikan pengaruh pemberian modal kerja dan biaya produksi terhadap Pendapatan Usaha Kecil Menengah di Desa Pongkar Kecamatan Tebing Kabupaten Karimun (Y) dilihat pada Tabel berikut ini.

Tabel Nilai Penduga Koefisien Regresi

\begin{tabular}{|c|c|c|c|c|}
\hline No & Variable & Koef. Regresi & t-statistik & Prob \\
\hline 1 & Constant & 30428502 & 3.041512 & 0.0047 \\
\hline 2 & $\left(\mathrm{X}_{1}\right)$ & 0.530164 & 3.036668 & 0.0047 \\
\hline 3 & $\left(\mathrm{X}_{2}\right)$ & 1.348602 & 4.037941 & 0.0003 \\
\hline \multicolumn{5}{|c|}{ R-Squared = 0.263491 } \\
\hline F-statistic $=\mathbf{5 . 7 2 4 1 0 9}$ & Prob (F-statisic) $\mathbf{= 0 . 0 0 7 4 9 6}$ \\
\hline
\end{tabular}

Sumber: Olahan Data Sekunder, Tahun 2019. 


\section{KESIMPULAN}

\section{A. Kesimpulan}

1. Berdasarkan hasil estimasi yang dilakukan melalui regresi data panel dalam penelitian ini, secara parsial variable $\left(\mathrm{X}_{1}\right)$ pemberian modal kerja memiliki pengaruh yang signifikan positif terhadap pendapatan usaha kecil menengah di Desa Pongkar Kecamatan Tebing Kabupaten Karimun (Y), hal ini dibuktikan dengan nilaip robabilitas $X_{1}$ sebesar $0,0047<$ alpha 0.05. Besaran pengaruh (koefisien regresinya sebesar 0.530164 , artinya setiap perubahan variable $\mathrm{X}_{1}$ sebesar 1 persen, akan berpengaruh terhadap Variabel $\mathrm{Y}$ sebesar 0.530164 persen, dengan asumsi cateris paribus/factor lain dianggap tetap.

2. Berdasarkan hasil estimasi yang dilakukan melalui regresi data panel dalam penelitian ini, secara parsial variable biaya produksi $\left(\mathrm{X}_{2}\right)$ memiliki pengaruh yang signifikan terhadap pendapatan usaha kecil menengah di Desa Pongkar Kecamatan Tebing Kabupaten Karimun (Y), hal ini dibuktikan dengan nilai probabilitas $\mathrm{X}_{1}$ sebesar $0,0003<$ alpha 0.05 . Besaran pengaruh (koefisien regresinya sebesar 1.348602, artinya setiap perubahan variable $\mathrm{X}_{2}$ sebesar 1 persen, akan berpengaruh terhadap Y sebesar 1.348602, satuan, dengan asumsi cateris paribus/factor lain dianggap tetap.

3. Secara bersama-sama atau simultan variabel $X_{1}$ pemberian modal kerja, dan variabel $\mathrm{X}_{2}$ biaya produksi terdapat pengaruh yang signifikan terhadap variable Y pendapatan usaha kecil menengah di Desa Pongkar Kecamatan Tebing Kabupaten Karimun, hal ini dibuktikan dengan nilai Prob (F-statistic) sebesar 0.007496 < alpha 0,05 . Nilai $\mathrm{R}^{2}$ Sebesar 0.263491 , artinya sebesar 26,3 persen variable $\mathrm{X}_{1}$ dan $\mathrm{X}_{2}$ berpengaruh terhadap variable $\mathrm{Y}$, selebihnya dipengaruhi oleh variable lain yang tidak dijelaskan dalam penelitian ini (74,7 Persen).

\section{B. Saran}

1. Pemerintahan Desa Pongkar Kecematan Tebing Kabupatan Karimun setidak nya dapat memberikan bantuan dana BUMDes (Badan Usaha Milik Desa) yang lebih besar lagi kepada para pelaku UKM di Desa Pongkar Kecematan Tebing Kabupaten Karimun, agar pendapatan para pelaku UKM lebih meningkat lagi.

2. Para pelaku UKM di Desa Pongkar Kecematan Tebing Kabupaten Karimun diharpkan meminimalisir biaya produksinya seproduktivitas mungkin, agar dapat meningkatkan pendapatan usaha nya. 


\section{DAFTAR PUSTAKA}

\section{Buku-buku:}

Ansofino, dkk. 2016. BukuAjarEkonometrika. Yogyakarta: Deepublish.

Bambang Riyanto, 2001. Dasar-Dasar Pembelanjaan Perusahaan, Yogyakarta : BPFE.

Baroto, Teguh. 2002. Perencanaan dan Pengendalian Produksi. Jakarta : Ghalia Indonesia.

Damanhuri, S. Didin Dan Muhammad Findi, 2014. Masalah Dan Kebijakan Ekonomi Indonesia, Bogor : PT. Penerbit IPB Pres.

Fahmi, Irham. 2012, Analisis Kinerja Keuangan, Bandung: Alfabeta.

Hartono, Jogiyanto. 2010. Metodologi Penelitian Bisnis: Salah Kaprah dan Pengalamanpengalaman, Edisi Pertama. Yogyakarta: BPFE.

Hasan, Iqbal. 2004. Analisis Data Penelitian dengan Statistik, Jakarta : PT Bumi Aksara.

Juanda, Bambang dan Junaidi. 2012. Ekonometrika Deret Waktu Teori dan Aplikasi. Bogor: IPB Press.

Kasmir, 2010. Analisis Laporan Keuangan, Jakarta : PT. Raja Grafindo Persada.

Kusnadi, 2000, Akuntansi Keuangan Menengah (Intermediate, Prinsip, Prosedur, dan Metode, Universitas Barawijaya Malang.

Lukman Syamsudin, 2007, Manajemen Keuangan Perusahaan, Jakarta: PT. Raja Gragindo.

M.Munandar, 2006. Pokok Intermediate Accounting, Yogyakarta: Gadjah Mada University Press.

Mulyadi. 2012. Akuntansi Biaya, Edisi ke-5. Cetakan Kesebelas, Yogyakarta; STIM YKPN.

Munawir, 2014. Analisa Laporan Keuangan. Yogyakarta : Liberty.

Nachrowi, Nachrowi Djalal dan Usman, Hardius. 2002. Penggunaan Teknik Ekonometrika. Jakarta: Raja Grafindo Persada.

Setiawan \& Dwi Endah Kusrini. 2010. Ekonometrika. Yogyakarta, CV. ANDI OFFSET.

Sugiyono, 2017. Metode Penelitian Kuantitatif, Kualitatif Dan R\&D, Bandung : Alfabeta.

Suliyanto.2011. Ekonometrika Terapan - Teori dan Aplikasi dengan SPSS. Yogyakarta: CV. ANDI OFFSET.

Supranto, J. 2010. Ekonometrik. Bogor: PenerbitGhalia Indonesia.

Supriady, Edy. 2014. SPSS + AMOS. Jakarta: Penerbit IN MEDIA.

Supriyono, R.A. 2013. Akuntansi Biaya, Buku 2, Edisi 2, yogyakarta: BPFE. 
Wibowo, Sampurno dan Yani Meilani, 2009, Akuntansi Biaya, Bandumg; Politeknik Telkom.

Widarjono, Agus. 2015. Analisis Multivariat Terapan dengan Program SPSS, AMOS, dan SMARTPLS. Yogyakarta: UPP STIM YKPN. 